\title{
眼窩吹抜け骨折の治療成績と複視の回復経過
}

\author{
藤野 清大・徳田 安誠 \\ 大田 耕造・伊藤 壽一
}

\section{Blowout Fractures and Postoperative Improvement of Diplopia}

\author{
Kiyohiro Fujino, Yasumasa Tokuda, \\ Kozo Ota and Juichi Ito \\ (Otsu Red Cross Hospital)
}

Forty-six patients with blowout fracture were treated surgically in Otsu Red Cross Hospital (23 with pure type, and 23 with impure type). Diplopia was present in $61 \%$, and in all of them, it was improved by surgery. We evaluated the degree of diplopia quantitatively by an index calculated from the Hess screen test before and after operation. (1) Diplopia on upward gaze improved more slowly than that on downward gaze. (2) Horizontal diplopia improved faster than vertical diplopia. (3) The degree of improvement showed no difference between patients with early and those with late operations.

Key words: blowout fracture, diplopia, Hess screen test

\section{はじめに}

当院は県内最大規模の救急指定病院という性 格上，外傷患者が多いといらことを一つの特徵 としている. 当科に括いても骨折を中心とした 顔面外傷を多数扱っているが，本稿では複視な ど多彩な症状を呈する眼窩吹抜け骨折 (blowout fracture) についてその治療成績を検討し， 特に長期的に見た術後の複視の改善度に関する 分析を試みた。

\section{対象および方法}

1) 対 象

対象は, 昭和 61 年 1 月より平成 3 年 5 月まで の約 5 年半の間に当科に括いて手術治療を行な った眼窩吹抜け骨折46例である。性別では男性 37例，女性 9 例とその比は約 $4: 1$ であった. 年齢分布を図 1 に示したが，10代・20代の若年
層で全体のちょらど半数の23例を占めている.

2 ) 複視の客観的評価法について

本報告の主目的は，長期的にみた術後の複視 の改善度に関する分析であるが，そのためには 患者の自覚的な症状の訴光の他に, 複視の程度 を客観的・定量的に評価できる尺度が存在する ことが望ましい，我々はこの尺度として，眼科 で一般的に行なわれているHess 赤緑試験 ${ }^{1)}$ 数值化を行ない，これをもとにして複視の程度 の経時的変化の分析を試みた。なお，Hess赤 緑試験の数值化自体は，すでに宗ら ${ }^{2)}$ 抢よび山 上ら によよて行なわれており，特に宗らの方 法は “RG 值”として多数の報告で複視の評価 に用いられているが，今回我々は後者の山上ら の方法に準じた評価法を用いた.

図 2 に Hess 赤緑試験の原理を示した。被検 
者の健眼に赤, 患眼に緑の眼鏡をかけさせ，赤 で描かれた碁盤目状のスクリーン(Hess チャー ト）を見せる.チャートの一目盛りは 50 で， 太線で示された“田”の字の内部は正面視から 上下左右各 $15^{\circ}$ の範囲を表している．被検者 に“田”の字上の一点(例えば点 e )を注視させ, その点に被検者の手にもたせた緑色のスポット ライトを重ねるように投影させる。この際，チ ャート上の点は赤色の眼鏡をかけた方の眼での み，スポットライトは緑色の眼鏡をかけた方の 眼でのみ見光るよらになって扔り，点 e 亿対す るスポットライトの位置 $\left(\mathrm{e}^{\prime}\right)$ は, 赤色の眼鏡を かけた眼(健眼)を基準としたときの緑色の眼鏡 をかけた眼(患眼)の眼位を表すことになる。も し両眼視機能が正常であれば(眼球運動が正常 であれば)両者は一致するが，患眼に眼球運動 制限があれば $\mathrm{e}^{\prime}$ は制限の㗢く方向にずれる.

“田”の字上の各交点 $\mathrm{a} \sim \mathrm{i}$ のすべてについて 同様の方法で $\mathrm{a}^{\prime} \sim \mathrm{i}^{\prime}$ の位置を決めると患眼の眼 位の軌跡が得られるが，この得られた“田”の 字はもとの位置に比べて眼球運動制限の働く方 向にずれ，もとの形に比べて制限のある方向に 圧縮された形となる。具体例として, 図 3 亿眼 窩底骨折で, 眼球の上転障害のある症例の Hess チャートを示した。

眼球運動制限の強さ即ち複視の程度は, Hess チャート上の “田”の字の位置の本来の
位置からのずれが大きいほど，またその形が圧 縮される比率が高いほど強いといらことになる。 そこで, 複視の程度の定量化のパラメーターと しては，厳密にはこの “位置のずれの大きさ” および “圧縮の程度”の両者を用いるべきであ ろらが，本報告では便宜上後者のみを定量化し て複視の程度を判定することにした。

図 3 を例としてHess チャートのスコア化の 方法を示す，例えば上方視に関しては，まず点

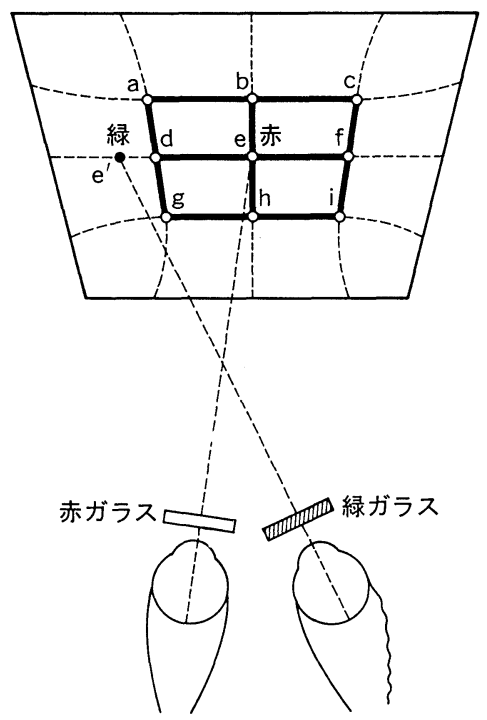

図 2 Hess 赤緑試験の原理 図は右外直筋麻痺の例

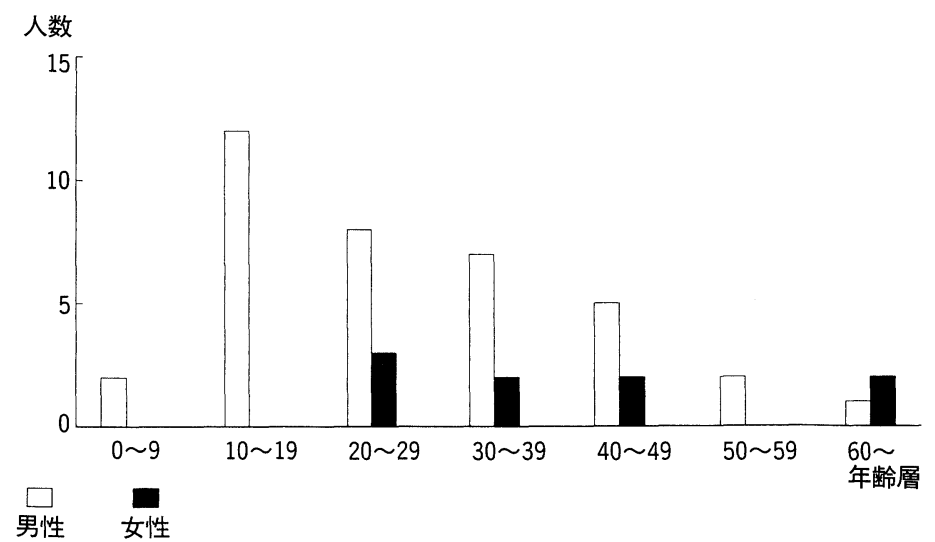

図 1 年齢分布 
$\mathrm{a}^{\prime}$ と点 $\mathrm{d}^{\prime}$ の距離の垂直方向成分を計測し(チ ャ一トの一目盛りは $5^{\circ}$ ), その值(実際の単位 は“度”) 10 を求める(この際, チャート上の線 は直線ではなく双曲線であるため厳密な意味で の測定はできないが，1 未満の端数の四捨五入 も含めて和执よそのところを目分量で行なら). 同様に $\mathrm{b}^{\prime}$ と $\mathrm{e}^{\prime} ， \mathrm{c}^{\prime}$ と $\mathrm{f}^{\prime}$ の垂直距離をそれぞれ 求め, この三者の合計 $10+10+11=31$ を方

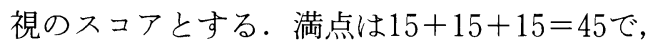

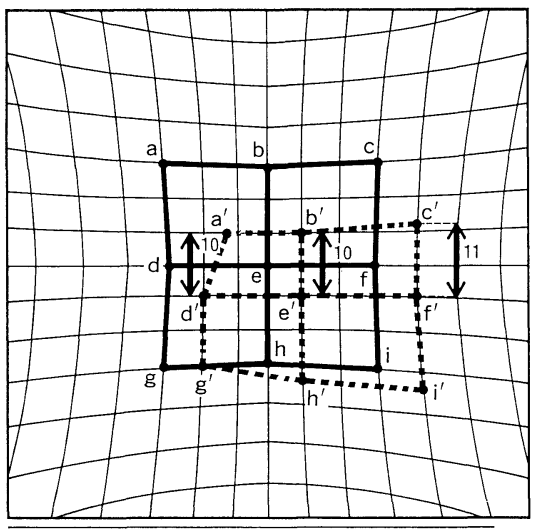

上方視のスコア $10+10+11=31$

図 3 眼窩底骨折例の Hess チャート チャートのスコア化の方法
スコアが小さい汪ど複視の程度が強いと考劣て よい. 下方視，内方視，外方視に関してもスコ アの求め方は全く同様で(後二者では距離の水 平方向成分の合計)，それぞれ34，42，45と求 められ，主として上・下方視が障害されている パターンが数字だけから読み取れる。

\section{結果}

1 ）骨折部位・形態，受傷原因

46例中，眼窩壁のみの骨折例，いわゆる“純 粋型”の吹抜け骨折は23例で，その内訳は表 1 に示すように眼窩底 12 例, 眼窩内側壁 8 例, 眼 窩底+眼窩内側壁 3 例であった．眼窩壁以外の 骨折を合併する “非純粋型” に捇ける同時骨折 部位としては上顎洞前壁が最も多く, 次いで煩 骨の順であった。

表 1 骨折部位

\begin{tabular}{l|c|c|c}
\hline \hline & 純 粋 型 & 非純粋型 & 計 \\
\hline 眼窩底 & 12 & 18 & 30 \\
\hline 眼窩内側壁 & 8 & 0 & 8 \\
\hline 眼窩底十内側壁 & 3 & 5 & 8 \\
\hline \multicolumn{1}{c|}{ 計 } & 23 & 23 & 46
\end{tabular}

表 2 骨折形態

\begin{tabular}{c|c|c|c|c}
\hline & 線 状 骨 折 & 打ち抜き型骨折 & 粉 砕 骨 折 & 計 \\
\hline 眼窩底 & 26 & 9 & 3 & 38 \\
\hline 眼窩内側壁 & 5 & 6 & 5 & 16 \\
\hline 計 & 31 & 15 & 8 & 54
\end{tabular}

※ 眼窩底，内側壁の同時骨折例ではそれぞれを 1 カ所と数えたため骨折部位の合計 は症例数より多くなっている.

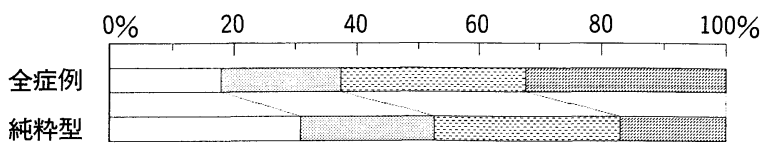

$\square$ スポーツ けんか 転倒転落 交通事故

図 4 受傷原因 
骨折形態を，(1)線状骨折，(2)打ち抜き型骨折， (3)粉䂶骨折の 3 型に分類して骨折部位別に表 2 に示した。眼窩底では大半が線状骨折であるの に対し，内側壁では打ち抜き型・粉砕型の比率 が高い，打ち抜き型・粉砕型では全例に眼窩内 容物の脱出を認めたが，線状骨折に执いて眼窩 内容物の嵌頓を認めたものは31例中22例であり, らち外眼筋そのものが嵌頓していたのは 2 例 （いずれも下直筋）であった。

また，全症例と純粋型症例のみ，とに分けて， 受傷原因の内訳を図 4 に示したが，全症例では 交通事故が，純粋型に限ればスポーツと転倒・ 転落が同数で最多となっている.

2 ) 臨床症状

眼窩吹抜け骨折に特徵的とされる 6 症状，(1) 複視, (2)視力障害, (3)眼球陥凹, (4)眼瞼気腫, (5)鼻出血，(6)嘔気・嘔吐につき，その出現頻度 を表 3 に示した(1)・(2)は自覚症状).

次に，初診時複視のあった 28 例について，そ の出現方向(どの方向を注視したときに自覚す
るか)を骨折部位別に表 4 にまとめた.

3 ) 手術適応 ・ 時期 - 方法

受傷から手術までの期間を表 5 に示した。当 科では純粋型の吹抜け骨折に関しては, 原則的 に，初診時に複視があり $1 \sim 2$ 週間の観察期間 中に自然治癒傾向のないものを手術適応として いる(非純粋型に関しては, 他部位の骨折に対 する整復の必要性の問題から, これょり適応は 広くなる)。このため手術時期は受傷後 3 週間 以内のものが大半を占めるが，手術時期がこれ より遅れた例に関してはその理由は，(1)受診そ のものが遅かった，(2)他の重大な合併損傷(頭 部など)の治療を優先させたなどである。また 複視がなくとも手術を行なった例については， その理由は擤鼻時の眼瞼腫脹などの不快な自覚 症状のあったものが汪とんどである。

手術に拈けるアプローチ方法を骨折部位別に 表 6 に示した，我々は純粋型の眼窩底あるいは 内側壁骨折では，それぞれ眼下切開・内眼角切 開(キリアン法)を原則とし, 脱出した眼窩内容

表 3 臨床症状

\begin{tabular}{|c|c|c|c|c|c|c|}
\hline & 複 視 & 視力障害 & 眼球陥凹 & 眼瞼気腫 & 鼻 出 血 & 嘔気 - 嘔吐 \\
\hline 全 症 例 & $61 \%$ & $26 \%$ & $22 \%$ & $17 \%$ & $41 \%$ & $11 \%$ \\
\hline 純粋型のみ & $78 \%$ & $26 \%$ & $26 \%$ & $30 \%$ & $30 \%$ & $13 \%$ \\
\hline
\end{tabular}

表 4 複視の出現方向

\begin{tabular}{l|c|c|c|c|c|c|c}
\hline \hline & 上 方 & 上十下方 & 内 方 & 外 方 & 上十内方 & 全 方 向 & 計 \\
\hline 眼窩底 & 9 & 5 & 0 & 0 & 2 & 0 & 16 \\
\hline 眼窩内側壁 & 0 & 0 & 3 & 2 & 1 & 0 & 6 \\
\hline 眼窩底+内側壁 & 1 & 1 & 0 & 0 & 1 & 3 & 6 \\
\hline \multicolumn{1}{c|}{ 計 } & 10 & 6 & 3 & 2 & 4 & 3 & 28
\end{tabular}

表 5 受傷から手術までの期間

\begin{tabular}{c|c|c|c|c|c|c}
\hline \hline 手術時期 & $\sim 1$ 週 & $\sim 2$ 週 & $\sim 3$ 週 & $\sim 4$ 週 & $\sim 2$ カ月 & 2 カ月 \\
\hline 例 数 & 4 & 21 & 11 & 8 & 1 & 1
\end{tabular}


表 6 手術に括けるアプローチ方法

\begin{tabular}{|c|c|c|c|c|c|c|}
\hline & 眼下切開のみ & $\begin{array}{l}\text { 眼下切開 } \\
\text { +経上顎 }\end{array}$ & キリアンのみ & 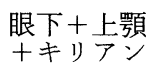 & 計 \\
\hline \multirow{3}{*}{$\begin{array}{l}\text { 純 } \\
\text { 粋 } \\
\text { 型 }\end{array}$} & 眼窩底 & 10 & 1 & 0 & 1 & 12 \\
\hline & 眼窩内側壁 & 0 & 0 & 8 & 0 & 8 \\
\hline & 眼窩底+内側壁 & 0 & 0 & 0 & 3 & 3 \\
\hline \multicolumn{2}{|c|}{ 非純粋型 } & 0 & 19 & 0 & 4 & 23 \\
\hline \multicolumn{2}{|r|}{ 計 } & 10 & 20 & 8 & 8 & 46 \\
\hline
\end{tabular}

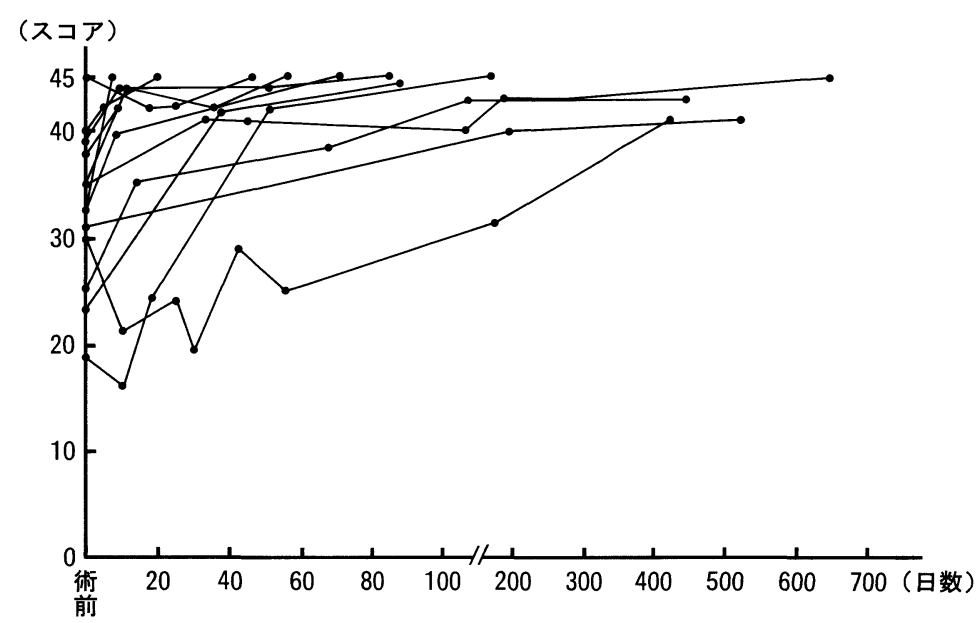

下方視の回復度

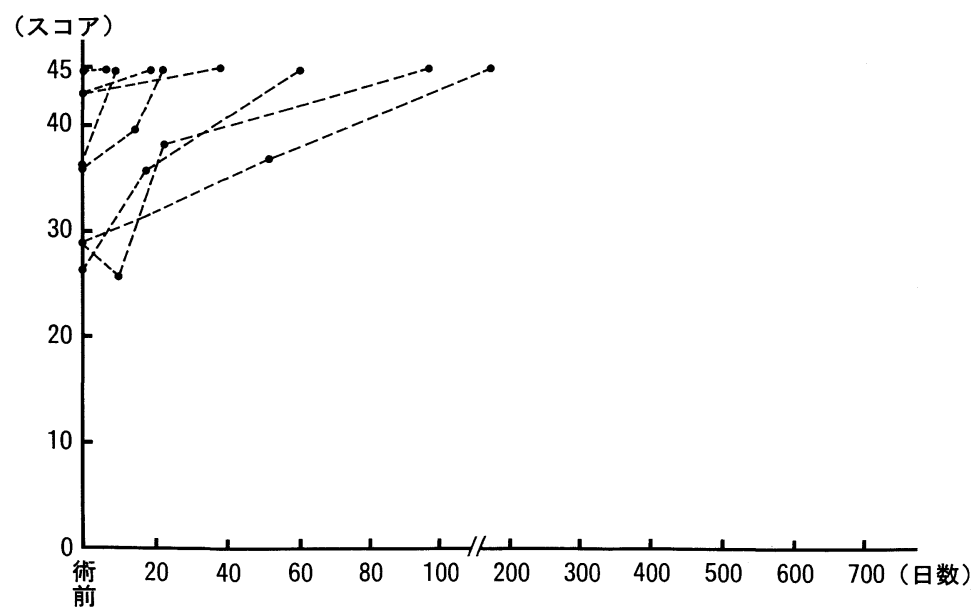

図 5 上方視と下方視の回復度の比較 
物の還納がこのアプローチだけでは不可能な場 合のみ，経上顎洞アプローチを追加している. 純粋型では概ね眼下あるいは内眼角切開のみで 整復できているのに対し, 非純粋型では全例に 経上顎洞アプローチが追加されているが，これ は同時骨折部位の大半に上顎洞前壁が含まれて いるためと, 眼窩壁骨折そのものの程度もひど く, 一方向からでは到底整復不能な症例が多か ったためである。

整復方法は, 脱出あるいは嵌頓した組織を眼 窩内へ還納したのち, 癒着があれば剥離してシ
リコンプレートを留置するというごく普遍的な ものである、シリコンプレートは骨欠損の大き さに応じて $0.5 \mathrm{~mm}$ または $1 \mathrm{~mm}$ 厚のものを使 い分けて扣り，ほぼ全例に使用した。

4 ）複視の術後経過 一自覚症状一

術前に複視の自覚があった28例に関しては, 全例が術後複視の改善があり, 不変または増悪 したものはなかった．らち最終的に完全治癒を 確認したのは18例であった. 治癒を確認してい ない残りの 10 例のらち, 術後 1 年以上複視の残 存した例が, 確認できた限りで少なくとも 6 例
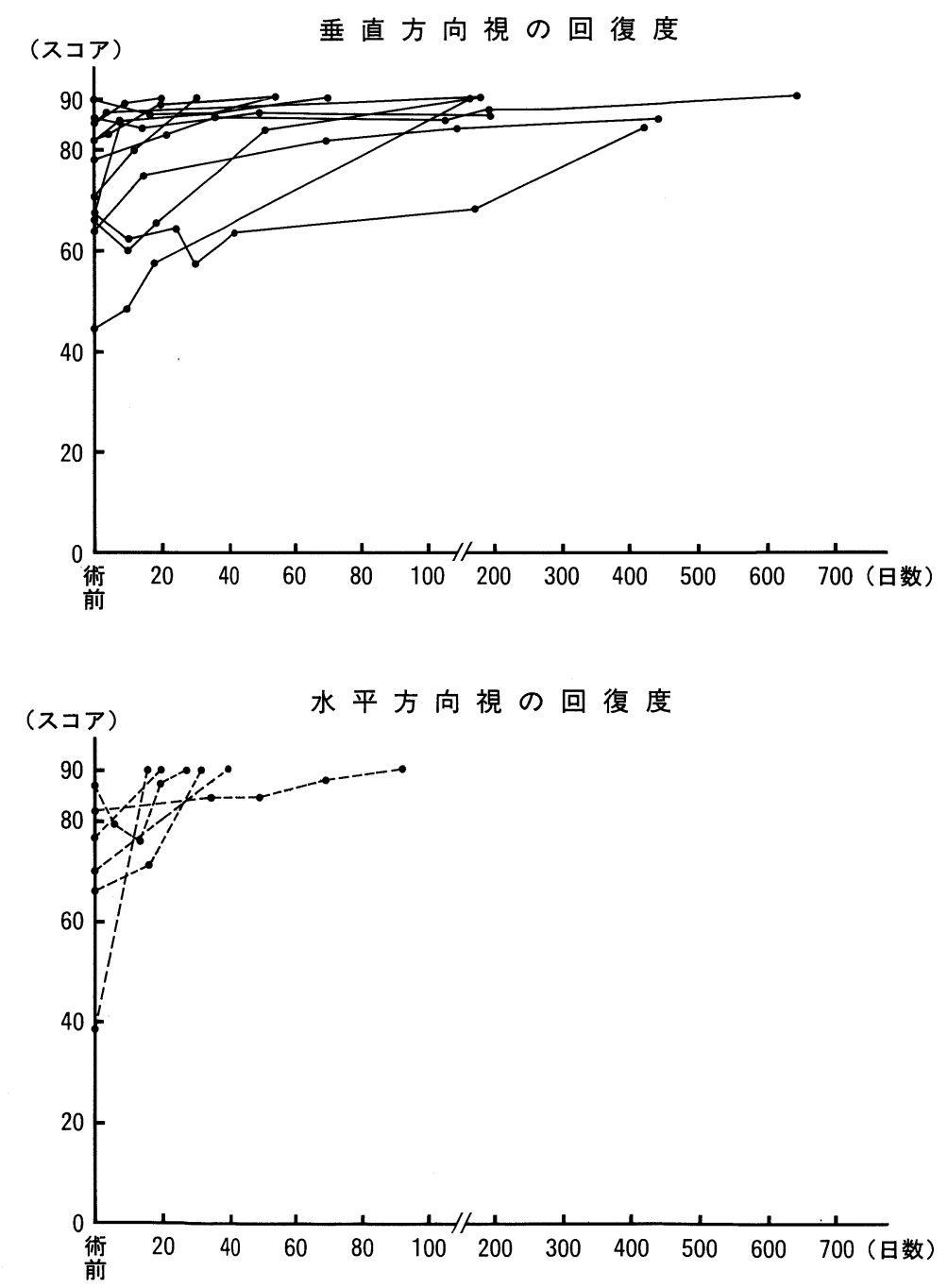

図 6 垂直方向視と水平方向視の回復度の比較 
あった．これら 6 例の複視の方向はすべて上方 であり，日常生活で常に自覚されるほど強いも のが 1 例, 普段は気付かないが強いて上方を注 視したときのみ自覚されるもの 5 例であった. また 6 例中 4 例が, 受傷後 15 日以降に手術が行 なわれた，非早期手術例であった。

5 ) 複視の術後経過 一スコア变化一

少なくとも術前術後に 1 回ずつ Hess 赤緑試 験を受けている32例についてスコアの経時変化
をまとめ，折れ線グラフに表した。な挔，術前 術後ともスコア満点のものはグラフから省いて ある。

(1)上方視と下方視の比較

図 5 に眼窩底骨折 20 例について，上方視と下 方視のスコア変化を比較して示した. 下方視に 比べて上方視の回復が遅れる傾向がグラフから 読及取れ, 最終的に満点に達しないものも数例 認められる。
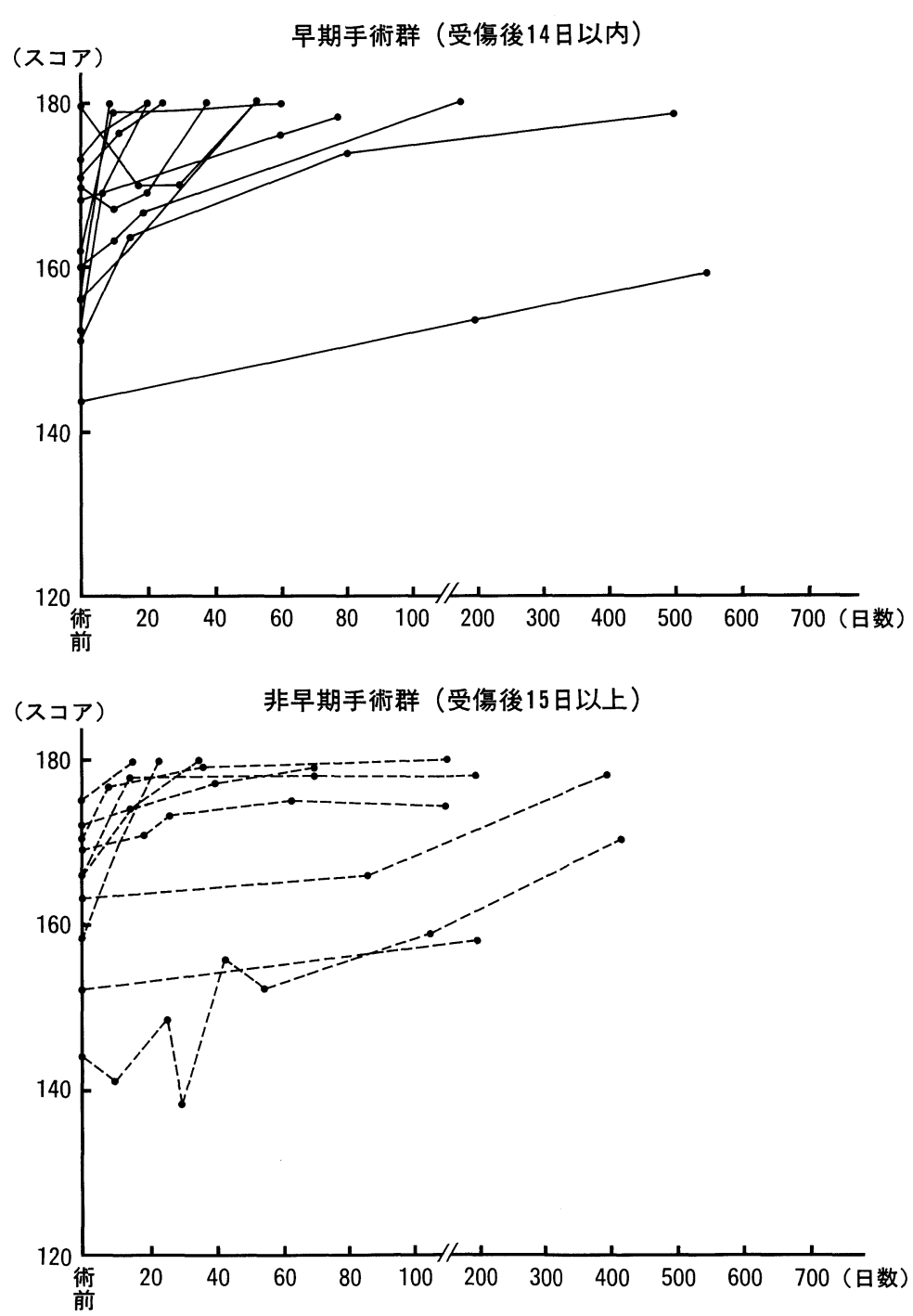

図 7 手術時期による回復度の比較 
(2)垂直方向視と水平方向視の比較

図 6 に眼窩底骨折20例に扮壮る垂直方向視 (上方と下方のスコアの合計 : 90 点満点) と, 眼 窩内側壁骨折 6 例に打ける水平方向視(内方と 外方のスコアの合計：90点満点)につき，スコ ア変化を比較して示したが，数は少ないものの， 水平方向視の方が回復が早い傾向であった.

(3)早期手術群と非早期手術群との比較 次に，全症例(32例)を受傷から手術までの日 数で, 早期手術群 (受傷後 14 日以内 : 18例), 非 早期手術群 (受傷後 15 日以上：14例)の二群化分 けて，スュア(全方向の合計：180点満点)の回 復を比較して図 7 に示した. 長期的には非早期 手術群の方に回復の遷延する例がやや目立つも のの, 全体としては両群の間にはっきりした回 復度の差はみられなかった。

\section{考按}

今回検討した対象, 骨折部位, 形態などは諸 家の報告とそれほど大差ない結果であった。

今回我々が複視の評価に用いた Hess 赤緑試 験のスコア化は, 複視の程度抢よび回復状態を 数字的に表現できる利点がある.これによると， 下方視に比べ上方視の回復が遅れる傾向があり, また垂直方向視に比べて水平方向視の方が回復 が早く, 内側壁骨折の予後は比較的良好である ことがわかった。

この Hess 赤緑試験のスコア化法は, 前述の ように山上ら ${ }^{3)}$ の用いた方法と注添同一のもの であり, 図 $5 \sim 7$ のスコア上の経過は患者の訴 える自覚症状の程度と概ね良い相関を示したが， 中には両者が乘離する例も見られた. 即ち， (1) スコアが満点でも複視が残っているもの, (2) ス コアが満点に達していないのに複視を自覚しな いものが認められた. (1)に関しては方法の項で も述べたように，このスコアには眼位のずれの 要素は入って抮らず, Hess チャート上の “田” の字の形と大ささが正常で, 位置のみがずれて いる例がこれにあてはまると考えられるほか， “田”の字の内部にあたる正面視から各方向 $15^{\circ}$ の範囲内では眼球運動制限がなく, これより外
の範囲でわずかに制限が残っている状態などが 考えられる。(2)に関しては，ある程度の複視は 中枢性に代償されるために自覚されないのでは ないかと推測される.

宗ら2)の考案した, 面積比で表す方法 “RG 值” は，(前述の眼位のずれの要素も含めて）一 つのパラメーターで複視を評価することができ る利点があるが，反面，垂直方向と水平方向に 分けて分析できない欠点があり，今回は用いな かった。

従来, 眼窩吹拔け骨折の手術適応 - 時期に関 しては，複視のあるものは全例早期に手術すべ

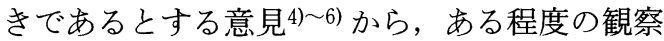
期間を括いて複視の自然治瘉傾向の有無を見極 めてから手術を行ならべきとするもの7) 11), 保存的治療を原則とし，早期手術は全く不要と するもの 12 ) 14) まで様々な見解があり，それぞ れが良好な治療成績を報告している．今回の報 告に执いては非手術例との比較検討は行なって おらず，また手術適応に関して明確な基準が定 められる核どの症例数ではないが，文献上，保 存的治療でも複視はある一定レベルまで改善す るが，最終的に完全治瘉に至らないものも多く， また，本報告の早期手術例のらち術前複視のあ った15例中で，複視が治癒しなかったのは 2 例 のみであったことなどから，当科に扮ける手術 適応・時期は，妥当なものであったと考学てい る。

\section{まとめ}

当科で手術治療を行なった眼窩吹抜け骨折 46 例について検討し, 特に術後の複視の改善度を Hess 赤緑試験のスコア化によって分析した。 その結果，以下のようなことが分った。

1) 上方視と下方視では，上方視の回復の方 が遅れる傾向が見られた。

2 ）垂直方向視と水平方向視では水平方向視 の回復の方が良好であった。

3 ) 早期手術例と非早期手術例との間には回 復度に明確な差はみられなかった。 
な拈，本論文の要旨は第53回耳鼻咽喉科臨床学会 (平成 3 年 7 月，札幌市) に扣いてロ演した.

\section{参考文献}

1) Hess WR : Ein einfaches messendes Verfahren zur Motilitätsprüfung der Augen. Z Augenheilkd $35: 201 \sim 219,1916$.

2）宗 信夫, 牧嶋和見 : 眼球運動障害改善の客観 的判定法 一Hess 赤緑試験の数值化一. 耳鼻 25 : 1349 1352, 1979.

3）山上美情子, 朴沢二郎, 斎藤久樹, 他 : 複視に 対する予後の面からみた眼窩らさぬけ骨折手術 療法の検討. 耳喉 $57: 1 ； 21 \sim 28,1985$.

4) Kirkegaard J, Greisen O and Højslet PE : Orbital floor fractures; early repair and results. Clin. Otolaryngol $11: 69 \sim 73,1986$.

5）深道義尚, 河井克化, 稲富 誠, 他 : Blowout fracture の予後について. 臨眼 $29: 63 \sim 66$, 1975.

6）越智利行：Blowout fracture の治療 一早期手 術について一。眼臨医報 $79: 365 \sim 369,1985$.

7）木村肇二郎，平形寿孝 : Blowout fracture の手 術例, 非手術例についての検討. 眼紀 32 : 1074 1079, 1981.

8) Dulley B and Fells P : Long-term folow-up of orbital blowout fractures with and without surgery. Mod Probl Ophthalmol 14 : 467 470,
1975.

9）馬嶋 孝, 吉田節子 : Blowout fracture の手術 適応について. 眼紀 $30:$ 187 194, 1979.

10) Emery JM, Von Noorden GK and Schlernitzauer DA : Orbital floor fractures, long-term follow up of causes with and without surgical repair. Trans Amer Acad Ophthalmol \& Otolaryngol $75: 802 \sim 812,1971$.

11）中川 喬, 木村早合子, 中嶋乃婦子, 他 : 眼窩 骨折の臨床経過および予後. 臨眼 31:509〜 513, 1977 .

12) Allen MP, Thomas S and Martin JU : Nonsurgical management of blow-out fractures of the orbital floor. Am J Ophthalmol 77 : 232 239, 1974.

13）牧野惟男：眼窩ふさぬ㚈骨折 -Blowout fracture一. 眼科 $29: 1089 \sim 1098,1987$.

14）田辺由紀夫, 中島裕美, 八木橋修: 眼窩吹き抜 け骨折に対する観血的治療は必要か？(予報). 臨眼 $44: 890 \sim 891,1990$.

$\left(\begin{array}{l}\text { 原稿受付: 平成 } 3 \text { 年 } 7 \text { 月 } 31 \text { 日 } \\ \text { 原稿採択 : 平成 } 3 \text { 年 } 11 \text { 月 } 5 \text { 日 } \\ \text { 別刷請求先 : 藤野清大 } \\ \text { ⿳亠丷厂巾 } 520 \text { 大津市長等 } 1-1-35 \\ \text { 大津赤十字病院耳鼻咽喉科 }\end{array}\right)$

